\title{
HAND CALCULATION AND EXTENDED THREE DIMENSIONAL ANALYSIS OF BUILDINGS (ETABS) SOFTWARE: AN ANALYSIS AND DESIGN FOR A THREE (3) STORY BUILDINGS
}

\author{
John Louie A. Gagalang, CE \\ Laguna State Polytechnic University- Santa \\ Cruz-Main Campus, \\ Philippines
}

\author{
Rina J. Arcigal, Ed. D \\ Laguna State Polytechnic University- Santa \\ Cruz-Main Campus, \\ Philippines
}

Article DOI: https://doi.org/10.36713/epra6237

\begin{abstract}
Earthquakes are known to produce one of the most destructive forces on earth. It has been seen that during past earthquakes many of the building were collapsed. Therefore, realistic method for analysis and design are required. Performance Based Design is the modern approach for earthquake resistant design. It is an attempt to predict the performance of buildings under expected seismic event. It involves the calculation of load and total Seismic weight of building from that the base shear is calculated in different zone.

The study is carried out with the help of both manual calculations and ETABS software for a three story building in the campus. Analysis of structure is used to verify the fitness of the structure for use. To perform accurate analysis information such as structural loads, geometry, support condition and material properties should be determined. ETABS is the acronym of extended 3D analysis of building system is software developed by Computers and Structures, Inc. (CSI). ETABS is an engineering software product that can be used to analyze and design multi-story buildings using grid-like geometry, various methods of analysis and solution techniques, considering various load combinations. ETABS can also handle the largest and most complex building models, including a wide range of nonlinear behaviors, making it the tool of choice for structural engineers in the building industry. ETABS can be effectively used in the analysis and design of building structures which might consists of structural members like beams, columns, slabs, shear walls and the like.

To perform accurate analysis information such as structural loads, geometry, support condition and material properties should be determined. The results of such an analysis typically include support reactions, stresses and displacements. Advanced structural analysis may examine dynamic response, stability and nonlinear behavior.

KEYWORDS: Extended three analysis dimensional system, analysis and comparison, beams, building geometry, material properties
\end{abstract}

\section{INTRODUCTION}

Buildings constitute a part of the definition of civilizations, a way of life advanced by the people. The construction of buildings should be looked upon as a process responded to human requirements rather than as a product to be designed and built a great expense. It is well known fact that users of any software for structural analysis and design do not know whether the program is having any bugs or its correctness while using. Since any program developed may contain some error or bugs it is necessary for the users to check the model and analysis and design results manually.

To analyze and design the low and high rise building, one must analyze and design the elements that combined it, such slabs, beams, columns and footing. Large amounts of full hand calculation, analysis and design of low and high rise building concrete are used in the construction industry and most countries due to its availability. Concrete is arguably the most I important building material, playing a role in all structures. It has the virtue of versatility, i.e. its ability to be molded to take different shapes $n$ the structural work.

\section{Building Geometry}

In order to evaluate and optimize building geometry, different analysis cycles should be part of an integrated design process. This challenges the current traditional design paradigm with a performance-based design method (Aksamija \& Mallasi 2010).Traditional method has deficiencies because, 1.) It may include simplified assumptions based on rules-of-thumb which can be inaccurate, 2.) It may force an aesthetic feature without considering performance impacts, and 3.) It may not provide performance measurement/evaluation of a certain design solution.

Apparently, past research on utilization of simulation tools during the architectural design process indicates that despite the increase in number of available tools in the last decade, some architects and designers find it difficult to use these tools, since they are not compatible with the working methods and needs, or the tools are judged as complex and bulky (Gratia \& Herde 2002; Punjabi \& Miranda 2005). Computational analysis tools provide a method where design and analysis process can be integrated from the earliest stages of the design, and can also assist in design decision-making (Aksamija 2010). 


\section{Material properties}

Concerns deterioration of concrete and corrosion of reinforcing steel due to potentially aggressive environment, the designer has to identify and anticipate conditions of the environment where the structure will be located in order to take adequate provision for protection of the materials used in the structure.

Considering to satisfy rules related to the different exposure classes of the structural members are given such as: 1.) Minimum concrete strength class, 2.) Concrete composition, 3.) Minimum concrete cover to reinforcement and, for more critical exposure classes, 4.) Maximum allowed crack width. Concrete strength is used as indirect measure of concrete durability, on the basis of the assumption, that higher strength $\rightarrow$ less porous concrete $\rightarrow$ higher durability. Complementary information about the maximum water/cement ratio and minimum cement content per cubic meter of concrete. The result is a large variation of requirements in different places, (Beltran L., de Herde A. \& J. Hensen. 2009).

Base Shear

Determination of design earthquake forces is computed using equivalent static lateral method and dynamic analysis. In the first method, different partial safety factors are applied to dead, live, wind earthquake forces to arrive at the design ultimate load. Apparently, while considering earthquake effects, wind loads assuming that both severe wind and earthquake do not act simultaneously. In American and Australian code recommendations are similar but with different partial safety factors. The dynamic analysis involves the rigorous analysis of the structural system by studying the dynamic response of the structure by considering the total response in terms of component modal responses, (Wetter, M. 2011).

\section{METHODOLOGY}

- Creation of Grid points \& Generation of structure

- Defining of property

- Assigning of Property

- Assigning of Supports

- Defining of loads

- Assigning of Dead loads

- Assigning of Live loads

- Assigning of load combinations • Analysis • Design

\section{RESULTS AND DISCUSSION}

Comparison of Results of Area of Steel in Tension (AST)

\begin{tabular}{|c|c|c|c|}
\hline Parameters & $\begin{array}{c}\text { ETABS result for AST } \\
(\mathbf{m m})\end{array}$ & $\begin{array}{c}\text { Manual result of AST } \\
\left(\mathbf{m m}^{2}\right)\end{array}$ & $\begin{array}{c}\text { Percentage variation } \\
\text { of Moments (\%) }\end{array}$ \\
\hline $\begin{array}{c}\text { Support section of } \\
\text { Beams B80 }\end{array}$ & 3126 & 2103.14 & 1.67 \\
\hline $\begin{array}{c}\text { Midspan section of } \\
\text { beams B80 }\end{array}$ & 2013 & 1854.85 & 0.85 \\
\hline Column C24/C47 & 3128 & 4621 & 0.31 \\
\hline
\end{tabular}

\begin{tabular}{|c|c|c|c|}
\hline \multicolumn{5}{|c|}{ Comparison results of Moments } \\
\hline Parameters & $\begin{array}{c}\text { ETABS result for } \\
\text { moment (kNm) }\end{array}$ & $\begin{array}{c}\text { Manual result of } \\
\text { moments (kNm) }\end{array}$ & $\begin{array}{c}\text { Percentage variation } \\
\text { of Moments (\%) }\end{array}$ \\
\hline $\begin{array}{c}\text { Support section of } \\
\text { beams B80 }\end{array}$ & 446 & 387.10 & 5.76 \\
\hline $\begin{array}{c}\text { Midspan section of } \\
\text { beams B80 }\end{array}$ & 437 & 452.70 & 4.70 \\
\hline $\begin{array}{c}\text { Top section of Column } \\
\text { C42/ C47 }\end{array}$ & 321 & 331.15 & 8.75 \\
\hline $\begin{array}{c}\text { Bottom section of } \\
\text { Column C42/C47 }\end{array}$ & 167 & 181.51 & 6.42 \\
\hline
\end{tabular}

\footnotetext{
Average \% difference in AST $=(1.67+0.85+0.31) / 3$
}

$$
=0.943 \%
$$

Average $\%$ difference in Moments $=(5.76+4.70+8.75+6.42) / 4$

$$
=6.407 \%
$$

Therefore, the average \% difference in Area of Steel and Moments of the portal frame From ETABS software and manual calculation are obtained $0.943 \%$ and $6.407 \%$ respectively.

\section{CONCLUSION AND \\ RECOMMENDATIONS}

The design and analysis of the multistoried building is carried out by ETABS software and the same is carried out for a portal frame of the structure by manual calculation. The analysis of the structure is carried out manually with the help of Kani's Method and the design is carried out by Limit State Method. The results obtained from ETABS software and manual calculation are compared and it shows the average \% difference of Area of steel and moments of the portal frame as $1.12 \%$ and $6.44 \%$ respectively. Hence, after comparing ETABS software with manual calculation, it can be concluded that ETABS software gives nearly 
accurate results and can be used for the design and analysis of multistoried structures.

\section{REFERENCES}

1. Aksamija, A. 2009. "Integration in Architectural Design: Methods and Implementations." Design Principles and Practices: An International Journal 3 (6): 151-160.

2. Aksamija, A. 2010. "Analysis and Computation: Sustainable Design in Practice." Design Principles and Practices: An International Journal 4 (4): 291-314.

3. Aksamija, A. \& Z. Mallasi. 2010. "Building Performance Predictions: How Simulations Can Improve Design Decisions." Perkins +Will Research Journal 2 (2): 7-32. Attia S.,

4. Beltran L., de Herde A. \& J. Hensen. 2009. "Architect Friendly: A Comparison of Ten Different Building Performance Simulation Tools", In Proceedings of IBPSA '09 Buildings Simulation Conference, 204-211. Glasgow: The International Building Performance Simulation Association.

5. Gratia, E. \& de A. Herde. 2002. "A Simple Design Tool for the Thermal Study of an Office Building." Energy and Buildings, 34: 279-289.

6. Moon, H., Choil, M., Kim, S. and Ryu, S., 2011 "Case Studies for the Evaluation of Interoperability between a BIM Based Architectural Model and Building Performance Analysis Programs" In Proceedings of IBPSA '11 Buildings Simulation Conference, 1521- 1526. Sydney: The International Building Performance Simulation Association.

7. Punjabi, S. \& V. Miranda. 2005. "Development of an Integrated Building Design Information Interface”, In Proceedings of IBPSA '05 Buildings Simulation Conference, Montreal, pp. 969-976.

8. Wetter, M. 2011. "A View on Future Building System Modeling and Simulation", In Building Performance Simulation for Design and Operation, Hensen, J. and Lamberts, R., (eds.), Routledge, UK. O2012 ACEEE Summer Study on Energy Efficiency in Buildings 12

\section{ACKNOWLEDGMENTS}

Office of the President - LSPU

Administrators and Faculty Members of Laguna State Polytechnic University.

Research and Development Services Office-LSPU College of Engineering-LSPU Santa Cruz Campus 